\title{
湖沼に新たに放流された魚類の增殖に就て
}

\author{
竹 內 能忠
}

（㖤館离等水䨟學校）

On the Growth of Population of Fish Newly Liberated into a Lake.

\section{Yositada TakexouTt}

SYNOPSIS

A method for estimating the ultimate population of adult fish, when the equilibrium betwcen catch and recruițment due to liberation is attained, was developed. The method was applied to fishing of Himemasu (Oncorhynchus adonis (JordaN et Mc Gregor)) in Lake Towara, with slight modification, which was inevitable owing to the lack of complete statistics.

從來生産のそしかつた湖沼に有用魚が放流され、其後年々一定數の稚魚を放流して行くを き、どの位の親魚を漁爑するととが出來るが見積るととが出來れば、水蓙堽殖の上から有 益であらうと思はれる。

湖沼中の放流された魚の總數を $p$ ，每年放流される稚魚の數を $N$ とし、此の魚の增加が 次の法則に依り支配されると假定する

$$
\left.\frac{d p}{d t}=p_{(}^{\prime} \varepsilon-f-h p\right)+N
$$

但し $\varepsilon$ は自然塯加率， $f$ は漁獲率， $h$ は制限係數である。 $\varepsilon-f=\varepsilon^{\prime}$ として此の式を積分す れば

$$
p-p_{0}=\frac{2 N+\varepsilon^{\prime}\left(p+p_{0}\right)-2 h p p_{0}}{\sqrt{\varepsilon^{\prime 2}+4 N h}} \tanh \frac{\sqrt{\varepsilon^{\prime 2}+4 N h}}{2} t
$$

但し、 $p_{0}$ は $t=0$ に於ける $p$ の值である。最初から放流魚が棲んで居ないならば、始めて 放流の行壮れを年を $t=0$ と取つて $p_{0}=0$ と置けるから、簡單に

$$
p=\frac{2 N+\varepsilon^{\prime} p}{\sqrt{\varepsilon^{\prime 2}+4 N h}} \tanh \frac{\sqrt{\varepsilon_{2}^{\prime}+4 N h}}{2} t
$$

となる。 $t \rightarrow \infty$ になれば $\tanh \frac{\sqrt{\varepsilon^{\prime 2}+4 N h}}{2} t \rightarrow 1$ であるから、平衡に達した後の焦の總數 $p_{\infty}$ は

$$
p_{\infty}=\frac{\varepsilon^{\prime}+\sqrt{\varepsilon^{\prime 2}+4 N h}}{2 h}
$$

となる(1) 一しし、放流が始められた後數年閒相當に精しい調查が行壮れて居れば、それから

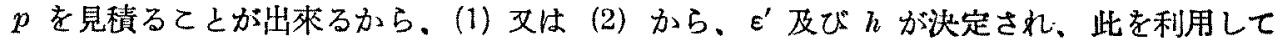
$p_{\infty}$ を豫想するてとが出來る。

十和田湖の姬解養殖事業に就いて之を㮣用して見る。此の場合には放流された稚魚數と。 漁獲された親魚の概數が刵つて居るだけであるから、上に迅べた通りに適用することが困難

（1）此の式は式 (1) で $d p / d t=0$ と䈯いて得られる。 
でする。それで、次のやうに變形する。

現在の場合に於いては、自然繁殖は殆んど行はれて居ないから、 $\varepsilon=-m$ とする。 $m$ は死

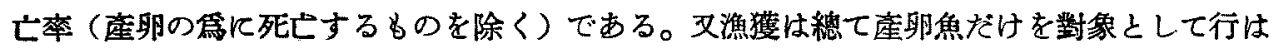
れるものと見て良いから、産卵期に達する迄は $f=0$

である。

初期 (明治三十六〜四十一年) 几於ける放流と再捕 の成樍は第1表に示すやうである。(1) 此の時代は魚の 總數が少いから (1) 式に於ける $h p$ の項は省略する ととが出來ると考へら礼る。此の表から自然の死亡率 を次のやうにして計算する。放流から再捕までの平均 年數は $(2.5 \times 1.2+3.5 \times 2.8+4.5 \times 0.12+5.5 \times 0.006) \div$ $4 \cdot 13=3 \cdot 23$ 年 となる。此の間に再捕されなかつを魚

\begin{tabular}{|c|c|c|c|}
\hline 年 & 月 & 放 流 & 再 捕 \\
\hline $\begin{array}{l}36 \\
37 \\
38 \\
39 \\
40 \\
41\end{array}$ & $\begin{array}{r}4 \\
10 \\
10 \\
10 \\
10\end{array}$ & 5 万尾 & $\begin{array}{l}\text { 二万尾 } \\
1 \cdot 2 \\
2 \cdot 8 \\
\cdot 12 \\
\cdot 006\end{array}$ \\
\hline \multicolumn{3}{|c|}{ 計 } & 4:126 \\
\hline
\end{tabular}
が死亡した早のよすれば、死亡率 $m$ は $4.126=5 \times e^{-m \times 3.23}$, 節ち $m=0.060$ となる。

大正九年以後に每年 500:萬尾放流し、近年は每年 80 萬尾を漁獲して居る。漁獲魯は主に 四年魚であるから、放流から漁獲されるまでの年數を 3.5 年上見る。現在に於いては淮獲以 外の原因に依る減亡は相當炕大きい。そのうち主なるのは、天然産卵をして漁獲されないも のが約 30 萬尾、密漁されるものが 10 萬尾、害敵（主に鵜）に食はれるものが 15 萬尾位 である。前の 2 者は全部座卵魚と考へても大きな誤を來をさないと思はれるから、㡾卵魚の 數は $80+30+10=120$ 萬尾と考へる。減亡率を $x$ とすれば $x=m+h p$ である。天然産卵 する親魚の數は相當に大きいけれども、産卵場が嫰くて何度も掘り返されるので邲化するも のは極めて少いから、之は無いものとする。そうすれば 500 莴尾 $\times e^{-3.5 x}=120$ 萬尾郎ち $e^{-3 \cdot 5 x}=0 \cdot 24, x=\frac{1 \cdot 43}{3 \cdot 5}=0.407$ と索る。

稚魚が放流された後、湖中に棲む魚の數を計算する。放流された稚魚の數を市とすれば。 二歲魚。三藏魚。四歲魚の數は夫文 $N e^{-x}, N e^{-2 x}, N e^{-3 x}$ で表はせるから、魚の總數 $p$ は

$$
p=N\left(1+e^{-x}+e^{-2 x}+e^{-3 x}=N \frac{1-e^{-4 x}}{1-e^{-x}}=500 \text { 萬 } \frac{1-0.198}{1-0.666}=500 \text { 萬 } \times 2.41=1205\right. \text { 萬尾 }
$$

よなる。隨つて $h=\frac{0.407-0.060}{1205 \times 10^{4}}=0.289 \times 10^{-7}$ となる。

此の $\dot{m}$ 及び $h$ を用ひて式 (3) に依り $p_{\infty}$ を計算すれば

$$
p_{\infty}=\frac{-.060+\sqrt{(.060)^{2}+4 \times 5 \times 10^{6} \times 0.29 \times 10^{-7}}}{2 \times 0.29 \times 10^{-7}}=\frac{-.060+0.765}{0.58} \times 10^{7}=1.21 \times 10^{7}
$$

となり前に計算した $p$ と變ら無い。故に、 $h$ を計算するとをに用ひられた假定が餘り不適 當をものでなかつたと云ふととが出來る。

次に、放流事業の初期に於いて、座卵魚が如何㗹加して行つたかを計算して見る。現在

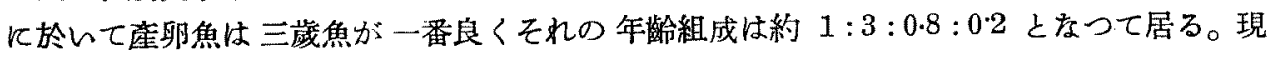
在の減亡率を考へに入れいば三歲魚の $\frac{1}{7}$, 四歲魚の $\frac{3}{5}$, 五歲魚の $\frac{5}{6}$ 及び 七歲魚の 荃部が 卵すると考へられる。文他方、最初に放流された 5 萬尾について見れば、それ等は $30 \%$ ，

（1）數字は總て和井內美魚場に於ける調查に侤る。 
$93 \%, 64 \%$ ，となつて居る。三歲魚, 四歳魚につれて雨者の平均を取れば、夫そ約 $\frac{1}{5}, \frac{3}{4}$

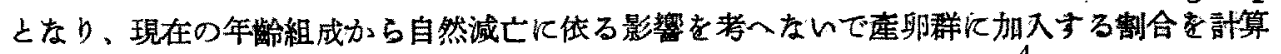

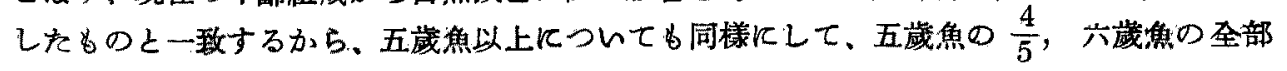
が、放流事業の初期に㕍卵群に加入したものとする。

此のやうにして、每年放流 後の魚數老計算し、それから 減亡率を求め、卵魚を除い て翌年の魚數を計算する。此 の方法を逐年絽返して、每年 の座畉魚數を求めたりのが第 2 表の第四列である。 此の表の座卵魚數之實際の 漁獲尾數とを比でて見ると。 每年の漁獾が一定で無いと考 一れば、大體の傾向に於いて

\begin{tabular}{|c|c|c|c|c|c|}
\hline \multirow{2}{*}{ 年 } & \multirow{2}{*}{ 度 } & \multirow{2}{*}{ 放流尾数 } & \multirow{2}{*}{ 漁獲尾数 } & \multicolumn{2}{|c|}{ 部算の結果 } \\
\hline & & & & 麾郋魚数 & 總 魚数 \\
\hline $\begin{array}{l}\text { 明治 } \\
\text { 大正 }\end{array}$ & $\begin{array}{r}39 \\
40 \\
41 \\
42 \\
43 \\
44 \\
45 \\
2 \\
3 \\
4 \\
5\end{array}$ & 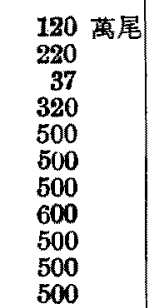 & $\begin{array}{c}\text { 二 萬尾 } \\
\overline{\mathbf{3 0}}^{\mathbf{3 0}} \\
\mathbf{4 0} \\
60 \\
60 \\
80 \\
\mathbf{1 2 0} \\
\mathbf{9 0} \\
\mathbf{8 5} \\
\mathbf{8 5}\end{array}$ & \begin{tabular}{l}
\multicolumn{1}{c}{ 萬尾 } \\
19 \\
79 \\
92 \\
65 \\
132 \\
160 \\
149 \\
155 \\
156
\end{tabular} & $\begin{array}{l}120 \text { 萬尾 } \\
329 \\
\mathbf{3 1 7} \\
576 \\
897 \\
1083 \\
1201 \\
1315 \\
\mathbf{1 2 4 0} \\
\mathbf{1 2 1 5} \\
\mathbf{1 1 9 8}\end{array}$ \\
\hline
\end{tabular}
は一致して居ると看做すことが出來やう。從つて上に計算された種ヶの數值は大體に於いて 正當度当のと認められる。 